\title{
PREPARATION， CHARACTERIZATION，THERMAL STUDIES, PHOTOCHEMICAL BEHAVIOURS AND ANTIMICROBIAL ACTIVITY OF COMPLEXES DERIVED FROM 5-METHYL-3-FURALDEHYDE THIOSEMICARBAZONE AND HG(II) SALTS OF HALLO ACIDS
}

\author{
Kamal S.T. Al-Jadabi* \\ Department of Chemistry, Faculty of Education-Arhab, Sana'a University, Sana'a, Yemen

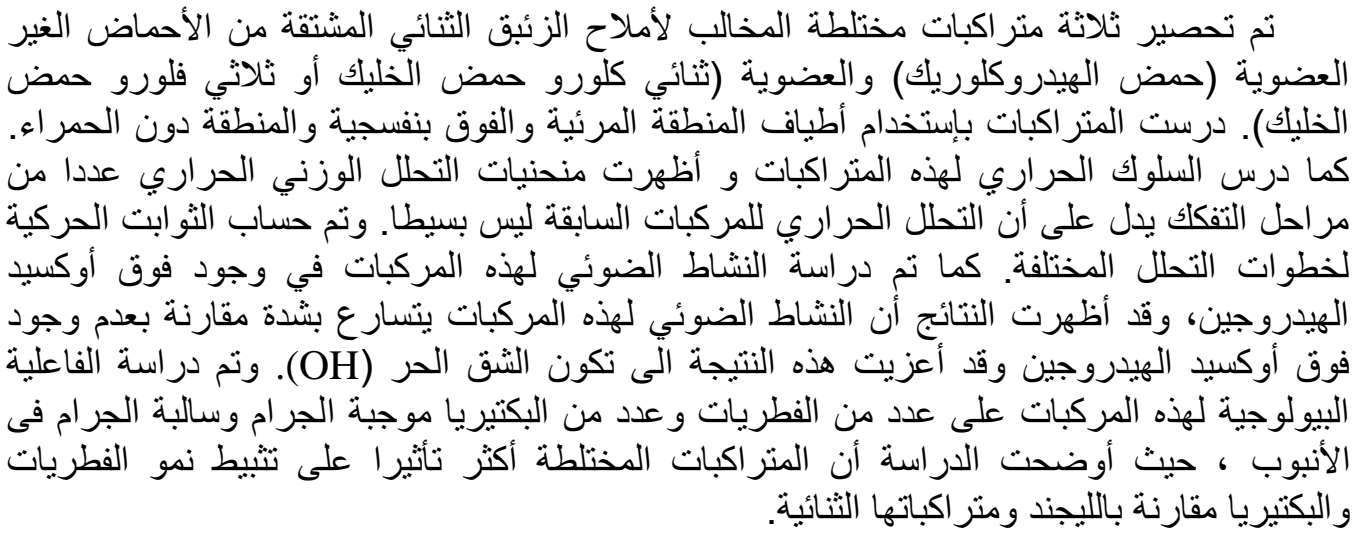

Complexes from of 5-methyl-3-furaldehydethiosemicarbazone (5M3HFTSC) and $\mathrm{Hg}(\mathrm{II})$ salts derived from inorganic $(\mathrm{HCl})$ and organic hallo acids $\left(\mathrm{CHCl}_{2} \mathrm{COOH}\right.$ or $\left.\mathrm{CF}_{3} \mathrm{COOH}\right)$ have been prepared. There chemical structures were characterized using elemental analyses, conductivity spectral measurements, thermogravimetric methods and photochemical behaviours. The thermal studies of such complexes using thermogravimetric analysis (TGA), derivatives thermogravimetry (DrTG) from ambient temperature to $750^{\circ} \mathrm{C}$ showed three decomposition steps. These studies indicated that the thermal decompositions are not simples. The photolysis of the studied compounds has been carried out in the presence of $\mathrm{H}_{2} \mathrm{O}_{2}$. It was found that, the photolysis was enhanced in the presence of $\mathrm{H}_{2} \mathrm{O}_{2}$ due to the generation of $\mathrm{OH}$ radicals which are very strong oxidizing agent. Biological activity of theses compounds was tested and screened for their in-vitro antibacterial and antifungal activity. The mixed ligand complexes generally are more active than the binary and free thiosemicarbazne ligand.

\section{INTRODUCTION}

Thiosemicarbazones are of significant interest not only for their chemotherapeutic activity against bacteria, viruses, fungi and cancer $^{1 \& 2}$, but also for their capacity for chemical recognition of anions and metals of biochemical medical and environmental importance $e^{3-5}$. They usually act as chelating ligands with metal ions, by bonding through semicarbazone sulfur and azomethine nitrogen atoms. When such ligands are complexed with metal ions their biological activities were enhanced $^{6}$. Accordingly, the present work involves preparation of complexes from 5methyl-3-furaldehydethiosemicarbazone with $\mathrm{Hg}(\mathrm{II})$ salts of inorganic acid $(\mathrm{HCl})$ and organic hallo acids (dichloroacetic acid (b) or trifloroacetic acid (c)) (Fig. 1). Spectroscopic characterization of such complexes using different techniques were performed. Biological studies of these compounds have been carried out in-vitro on some human pathogenic bacteria and fungi.

Received in 16/3/2010 \& Accepted in 4/8/2010 


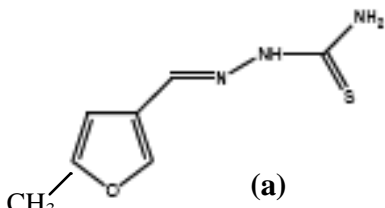

\section{$\mathrm{CHCl}_{2} \mathrm{COOH} \mathrm{CF}_{3}-\mathrm{COOH}$}

(b)

(c)

Fig. 1: The structures of 5-methyl-3-furaldehydethiosemicarbazones (5M3HFTSC) and hallo acids ligand.

\section{EXPERIMENTAL}

Solvents and reagents were of Analar grade and were obtained from commercial sources and used as such without further purification. Spectrograde solvents were used for spectral and conductance measurements.

\section{Preparation of ligand and complexes}

Salts of $\mathrm{Hg}$ (II) 1,1-dichloroacetate and 1,1,1-trifluroroacetate were obtained from the reaction of hall acids $\left(\mathrm{CHCl}_{2} \mathrm{COOH}\right.$ or $\mathrm{CF}_{3} \mathrm{COOH}$, respectively) and $\mathrm{HgCl}_{2}$ in ethanolic solution ${ }^{7}$. The 5-methyl-3furaldehyde thiosemicarbazone ligand was prepared by the methods reported earlier ${ }^{8-10}$. The $\mathrm{Hg}$ (II) binary complex of 5MHFTSC was prepared by mixing an ethanolic solution (20 $\mathrm{ml})$ of 5M3HFTSC $(2 \mathrm{mmol})$ with an ethanolic solution $(20 \mathrm{ml})$ of $\mathrm{HgCl}_{2}(1 \mathrm{mmol})$. The mixed was refluxed on a boiling water bath for $1 \mathrm{~h}$ to afford coloured solution. This solution was concentrated to half of them volume. After cooling to room temperature, crystalline solid was isolated, which was washed with ethanol and dried in vacuum. The mixed ligand complexes derived from 5M3HFTSC with $\mathrm{Hg}$ (II) salts of acids were prepared by adding an ethanolic solution (10 ml) of 5M3HFTSC (2 $\mathrm{mmol})$ to a $10 \mathrm{ml}$ ethanolic solution $(1 \mathrm{mmol})$ of the respective $\mathrm{Hg}$ (II) salts. Reaction mixture was heated under reflux for $1 \mathrm{~h}$ on a boiling water bath. On cooling, the solid complexes were separated out, filtered, washed repeatedly with ethyl alcohol, recrystallized from absolute ethanol and dried in vacuum.

\section{Physical measurements}

Electrical conductivity of $10^{-3} \mathrm{M}$ solution of the complexes were measured at room temperature by a Jenway 4330 conductivity meter. IR spectra were recorded on a 470 shimadzu infrared Spectrophotometer (4000$400 \mathrm{~cm}^{-1}$ ) using $\mathrm{KBr}$ disks. The electronic adsorption spectral measurements in the ultraviolet and visible regions were carried out in DMF on a UV-2102 PC Shimadzu Spectrophotometer using $1 \mathrm{~cm}$ matched quartz cell in the wavelength range 200-900 $\mathrm{nm}$. Elemental analyses of CHNS were determined by Gmbh Vario El analyzer. The thermogravimetric (TG) and differential thermal analysis (DTA) of the solid complexes were preformed using a DTG-60H thermogravimetric analyser (Shimadzu) from ambient temperature to $750^{\circ} \mathrm{C}$ with a $10^{\circ} \mathrm{C} \mathrm{min}^{-1}$ heating rate in dynamic air atmosphere. The photolyses were achieved using an Osram HBO 200 w/2 Lamp as a light source. Cut-one filter of 299 $\mathrm{nm}$ was used. Irradiations were carried out in DMF in 1-cm Spectrophotometer cells at room temperature. The photolysis progress was monitored by the above mentioned spectrophotometer.

\section{Biological data \\ 1. Materials and methods}

The 5M3HFTS ligand and its complexes were stored dry at room temperature and dissolved in dimethyl sulfoxide (DMSO) just before their use.

\section{Antibacterial and antifungal tests}

The antibacterial and antifungal properties of 5M3HFTSC and its complexes were determined by the standard "disc diffusion" $\operatorname{method}^{11}$. Here the bacteria and fungi were grown in nutrient and Sabouraud dextrose agar slants and the viable bacterial cells and fungal spore harvested into phosphate buffered saline and swabbed in to nutrient agar and Sabouraud dextrose agar plates, respectively. The compounds to be tested were dissolved in DMSO to a final concentration of $0.1 \%$ and soaked in filter paper discs of $5 \mathrm{~mm}$ diameter and $1 \mathrm{~mm}$ thickness. These filter papers were found to hold a quantity $0.01 \mathrm{~cm}^{3}$ solution. These discs were placed on already seeded plates and incubated at $28 \pm 0.4^{\circ} \mathrm{C}$ for 48 to 72 h. A clearing zone around the disc indicated the inhibitory activity of the compound on the organism.

\section{RESULTS AND DISCUSSION}

\section{Characterization of $\mathrm{Hg}(\mathrm{II})$ complexes}

The reported $\mathrm{Hg}$ (II) complexes provided satisfactory $\mathrm{C}, \mathrm{H}, \mathrm{N}$, and $\mathrm{S}$ analyses (Table 1) 
Table 1: Physical properties and elemental analysis of the 5-methyl-3-feuraldehydethiosemi carbazone and $\mathrm{Hg}$ (II) complexes.

\begin{tabular}{|c|c|c|c|c|c|c|c|}
\hline \multirow{2}{*}{$\begin{array}{l}\text { 5M3HFTSC and } \\
\text { complex }\end{array}$} & \multirow{2}{*}{$\begin{array}{c}\text { M. F } \\
\text { (M. Wt) }\end{array}$} & \multirow{2}{*}{ Colour } & \multirow{2}{*}{$\begin{array}{l}\mathrm{m} \cdot \mathrm{p} /{ }^{\circ} \mathrm{C} \\
\text { (Decomp) }\end{array}$} & \multicolumn{4}{|c|}{ Found / (Calc.) } \\
\hline & & & & $\mathrm{C} \%$ & $\mathrm{H} \%$ & $\mathrm{~N} \%$ & $\mathrm{~S} \%$ \\
\hline 5M3HFTSC & $\begin{array}{c}\mathrm{C}_{7} \mathrm{H}_{10} \mathrm{~N}_{3} \mathrm{OS} \\
(183.04)\end{array}$ & $\begin{array}{l}\text { Dark } \\
\text { brown }\end{array}$ & 179 & $\begin{array}{c}45.31 \\
(45.91)\end{array}$ & $\begin{array}{c}5.46 \\
(5.32)\end{array}$ & $\begin{array}{l}23.41 \\
(23.74)\end{array}$ & $\begin{array}{c}17.48 \\
(17.62)\end{array}$ \\
\hline$\left[\mathrm{Hg}(5 \mathrm{M} 3 \mathrm{HFTSC})_{2} \mathrm{Cl}_{2}\right]$ & $\begin{array}{c}\mathrm{C}_{14} \mathrm{H}_{20} \mathrm{Cl}_{2} \mathrm{HgN}_{6} \mathrm{O}_{2} \mathrm{~S}_{2} \\
(637.662)\end{array}$ & $\begin{array}{l}\text { Yellowish } \\
\text { brown }\end{array}$ & 293 & $\begin{array}{c}26.67 \\
(26.35)\end{array}$ & $\begin{array}{c}3.24 \\
(3.14)\end{array}$ & $\begin{array}{c}13.61 \\
(13.17)\end{array}$ & $\begin{array}{l}10.387 \\
(10.03)\end{array}$ \\
\hline $\begin{array}{l}{\left[\mathrm{Hg}\left(5 \mathrm{M} 3 \mathrm{HFTSC}_{2}\left(\mathrm{CF}_{3^{-}}\right.\right.\right.} \\
\left.\mathrm{COO})_{2}\right]\end{array}$ & $\begin{array}{c}\mathrm{C}_{18} \mathrm{H}_{20} \mathrm{~F}_{6} \mathrm{HgN}_{6} \mathrm{O}_{6} \mathrm{~S}_{2} \\
(792.66)\end{array}$ & $\begin{array}{l}\text { Light } \\
\text { Yellow }\end{array}$ & 319 & $\begin{array}{c}27.19 \\
(27.26)\end{array}$ & $\begin{array}{l}2.43 \\
(2.52)\end{array}$ & $\begin{array}{c}10.51 \\
(10.60)\end{array}$ & $\begin{array}{c}7.93 \\
(8.07)\end{array}$ \\
\hline $\begin{array}{l}{\left[\mathrm{Hg}(5 \mathrm{M} 3 \mathrm{HFTSC})_{2}\left(\mathrm{CHCl}_{2}\right.\right.} \\
\left.-\mathrm{COO})_{2}\right]\end{array}$ & $\begin{array}{c}\mathrm{C}_{18} \mathrm{H}_{22} \mathrm{Cl}_{4} \mathrm{HgN}_{6} \mathrm{O}_{6} \mathrm{~S}_{2} \\
(822.722)\end{array}$ & $\begin{array}{l}\text { Light } \\
\text { brown }\end{array}$ & 314 & $\begin{array}{c}26.83 \\
(26.26)\end{array}$ & $\begin{array}{c}2.92 \\
(2.67)\end{array}$ & $\begin{array}{c}10.42 \\
(10.21)\end{array}$ & $\begin{array}{c}7.89 \\
(7.78)\end{array}$ \\
\hline
\end{tabular}

which confirmed the general composition $\left[\mathrm{Hg}(5 \mathrm{M} 3 \mathrm{HFTSC})_{2} \mathrm{X}_{2}\right]$ (where $\mathrm{X}=\mathrm{Cl}^{-}, \mathrm{CHCl}_{2^{-}}$ $\mathrm{COO}^{-}$and/or $\mathrm{CF}_{3} \mathrm{COO}^{-}$). The formation of the complexes may be represented by the following equations.

$$
\begin{aligned}
& \mathrm{HgCl}_{2}+2(5 \mathrm{M} 3 \mathrm{HFTSC}) \underset{\left[\mathrm{Hg}(5 \mathrm{M} 3 \mathrm{HFTSC})_{2} \mathrm{Cl}_{2}\right]}{\longrightarrow} \\
& \mathrm{Hg}\left(\mathrm{CF}_{3} \mathrm{COO}\right)_{2}+2(5 \mathrm{M} 3 \mathrm{HFTSC}) \\
& {\left[\mathrm{Hg}(5 \mathrm{M} 3 \mathrm{HFTSC})_{2}\left(\mathrm{CF}_{3} \mathrm{COO}\right)_{2}\right]}
\end{aligned}
$$

\section{Conductivity measurements}

The molar conductance values of the complexes measured in DMF at the concentration $10^{-3} \mathrm{M}$ are 30,52 and $46 \mathrm{Ohm}^{-1}$ $\mathrm{cm}^{2} \mathrm{~mol}^{-1}$ for the $\left[\mathrm{Hg}(5 \mathrm{M} 3 \mathrm{HFTSC})_{2} \mathrm{Cl}_{2}\right]$, $\left[\mathrm{Hg}(5 \mathrm{M} 3 \mathrm{HFTSC})_{2}\left(\mathrm{CF}_{3} \mathrm{COO}\right)_{2}\right]$ and $[\mathrm{Hg}(5 \mathrm{M} 3-$ HFTSC $\left.)_{2}\left(\mathrm{CHCl}_{2} \mathrm{COO}\right)_{2}\right]$, respectively. These values indicate the electrolytic nature of the complexes ${ }^{12}$.

\section{Spectroscopic characterization 1- Infrared spectra}

Important IR bands for the ligand and complexes (Fig. 2) with their tantative assignment are presented in table 2 . The free 5M3HFTSC ligand showed $\mathrm{C}=\mathrm{N}$ at $1600 \mathrm{~cm}^{-1}$ and $\mathrm{C}=\mathrm{S}$ at $830 \mathrm{~cm}^{-1}$. On complexation, the position of these bands is shifted to lower frequency by ca. $10-15 \mathrm{~cm}^{-1}$ and $10-60 \mathrm{~cm}^{-1}$, respectively as reported ${ }^{13-18}$. This indicates that, coordination takes place through the azomethine nitrogen and sulfur of the $\mathrm{C}=\mathrm{S}$ group. This is further supported by appearance of new bands in the regions $435-455 \mathrm{~cm}^{-1}$ and $380-395 \mathrm{~cm}^{-1}$ for $v(\mathrm{M}-\mathrm{N})$ and $v(\mathrm{M}-\mathrm{S})$, respectively as reported ${ }^{19-23}$. Another medium- intensity band corresponding to $v(\mathrm{NH})$ is observed at $3110-3440 \mathrm{~cm}^{-1}$ indicating the thionic form of the ligands ${ }^{24-28}$. The position of this band did not change in the spectra of the complexes. This indicating that the $-\mathrm{NH}$ group does not take part in coordination.

\section{2- Electronic spectral studies}

The electronic spectral data of $\mathrm{Hg}$ (II) complexes under investigation display strong absorption bands at 33,958 ، 37,468 ، 32,751 $\mathrm{cm}^{-1}$ and 25,778 ، 29,421 ، 25,629 $\mathrm{cm}^{-1}$ (Table 3 ), these bands are assigned as $\pi-\pi^{*}$ transition and an intraligand charge(IL charge) transfer transition ${ }^{29}$.

$\mathrm{Hg}(\mathrm{II})$, being a $\mathrm{d}^{10}$ ion, does not show d-d transitions and, hence, the stereochemistry of its complexes cannot be determined from ultraviolet and visible spectra. However, from comparison between these $\mathrm{Hg}$ (II) complexes and complexes of similar environment around $\mathrm{Hg}(\mathrm{II})^{30-36}$, octahedral geometry is suggested for the prepared complexes.

\section{Thermal studies}

\section{1- Thermal behaviour}

The thermal behaviour of the $\mathrm{Hg}(\mathrm{II})$ complexes under investigation was studied in dynamic air using thermogravimetric analysis (TGA), derivatives thermogravimety (DrTG) and differential thermal analysis (DTA). The thermal decomposition of the complexes was recorded from ambient temperature to $750^{\circ} \mathrm{C}$ (Table 4). The results showed that the complexes generally decomposed in several thermal events, i.e., two or three decomposition steps. The first step for all complexes correlates well with the theoretical values corresponding to the elimination of the two hallo acid molecules present. The end products of the decomposition were identified from the TG traces to be $\mathrm{HgO}$. 


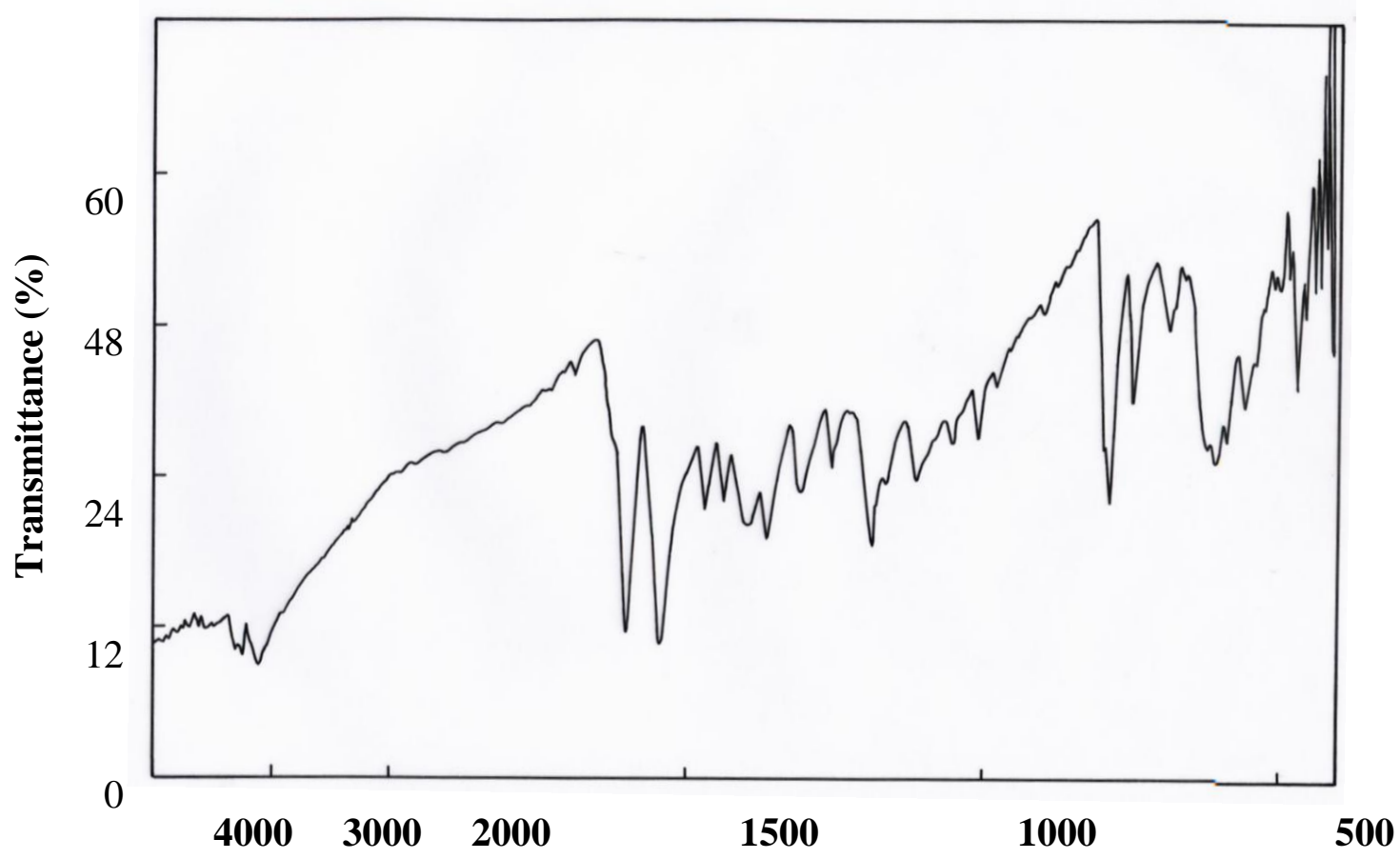

Fig. 2: IR spectrum of $\left[\mathrm{Hg}(5 \mathrm{M} 3 \mathrm{HFTSC})_{2}\left(\mathrm{CF}_{3} \mathrm{COO}\right)_{2}\right]$.

Table 2: IR spectral data $\left(\mathrm{cm}^{-1}\right)$ of free 5M3HFTSC and $\mathrm{Hg}$ (II) complexes.

\begin{tabular}{|c|c|c|c|c|c|}
\hline Complex & $\mathrm{v}\left(\mathrm{NH} / \mathrm{NH}_{2}\right)$ & $v(\mathrm{C}=\mathrm{N})$ & $v(\mathrm{C}=\mathrm{S})$ & $v(\mathrm{M}-\mathrm{N})$ & $v(\mathrm{M}-\mathrm{S})$ \\
\hline 5M3HFTSC & $3220-3450 m$ & $1600 \mathrm{~s}$ & $830 \mathrm{~s}$ & - & - \\
\hline$\left[\mathrm{Hg}(5 \mathrm{M} 3 \mathrm{HFTSC})_{2} \mathrm{Cl}_{2}\right]$ & $3110-3420 \mathrm{~m}$ & $1590 \mathrm{~s}$ & $820 \mathrm{~s}$ & $455 \mathrm{~s}$ & 395 \\
\hline $\begin{array}{l}{\left[\mathrm{Hg}\left(5 \mathrm{M} 3 \mathrm{HFTSC}_{22}\left(\mathrm{CF}_{3^{-}}\right.\right.\right.} \\
\left.\mathrm{COO})_{2}\right]\end{array}$ & $3220-3440 \mathrm{~m}$ & $1585 \mathrm{~s}$ & $790 \mathrm{~s}$ & $435 \mathrm{~s}$ & 380 \\
\hline $\begin{array}{l}{\left[\mathrm{Hg}(5 \mathrm{M} 3 \mathrm{HFTSC})_{2}\left(\mathrm{CHCl}_{2}\right.\right.} \\
\left.\mathrm{COO})_{2}\right]\end{array}$ & $3250-3400 m$ & $1588 \mathrm{~m}$ & $770 \mathrm{~m}$ & $440 \mathrm{~s}$ & 385 \\
\hline
\end{tabular}

s: strong, m: medium

Table 3: Electronic spectral data $\left(\mathrm{cm}^{-1}\right)$ of $\mathrm{Hg}(\mathrm{II})$ complexes.

\begin{tabular}{|c|c|c|}
\hline Complex & $v_{\max }\left(\mathrm{cm}^{-1}\right)$ & Assignment \\
\hline$\left[\mathrm{Hg}(5 \mathrm{M} 3 \mathrm{HFTSC})_{2} \mathrm{Cl}_{2}\right]$ & 25,778 & IL-charge transfer \\
\hline \multirow{2}{*}{$\mathrm{Hg}\left(5 \mathrm{M} 3 \mathrm{HFTSC}_{2}\left(\mathrm{CF}_{3}-\mathrm{COO}\right)_{2}\right]$} & 33,958 & $\pi-\pi *$ transition \\
\hline \multirow{2}{*}[\mathrm{Hg}(5\mathrm{M}3\mathrm{HFTSC})_{2}(\mathrm{CHCl}_{2}-\mathrm{COO})_{2}]{} & 37,468 & $\pi$ IL-charge transfer \\
& 25,629 & $\pi *$ transition \\
\hline
\end{tabular}


Table 4: Thermal decomposition data of $\mathrm{Hg}$ (II) complexes.

\begin{tabular}{|c|c|c|c|c|c|}
\hline \multirow{2}{*}{ Complex } & \multirow{2}{*}{$\begin{array}{c}\text { Ste } \\
\mathrm{p}\end{array}$} & \multicolumn{3}{|c|}{ TG/DTG } & \multirow{2}{*}{$\begin{array}{c}\text { Mass loss } \\
(\%)\end{array}$} \\
\hline & & $\mathrm{T}_{\mathrm{i}} /{ }^{\circ} \mathrm{C}$ & $\mathrm{T}_{\mathrm{m}} /{ }^{\circ} \mathrm{C}$ & $\mathrm{T}_{\mathrm{f}} /{ }^{\circ} \mathrm{C}$ & \\
\hline \multirow{3}{*}[\mathrm{Hg}(5\mathrm{M}3\mathrm{HFTSC})_{2}\mathrm{Cl}_{2}]{} & $1^{\mathrm{st}}$ & 191 & 220 & 278 & 11.7 \\
\hline & $2^{\text {nd }}$ & 279 & 303 & 346 & 5.2 \\
\hline & $3^{\text {rd }}$ & 347 & 513 & 579 & 49.3 \\
\hline \multirow{3}{*}[\mathrm{Hg}(5\mathrm{M}3\mathrm{HFTSC})_{2}(\mathrm{CF}_{3}\mathrm{COO})_{2}]{} & $1^{\text {st }}$ & 263 & 287 & 469 & 29.2 \\
\hline & $2^{\text {nd }}$ & 471 & 588 & 628 & 21.2 \\
\hline & $3^{\text {rd }}$ & 628 & 713 & 742 & 23.3 \\
\hline \multirow{2}{*}{$\begin{array}{l}{\left[\mathrm{Hg}(5 \mathrm{M} 3 \mathrm{HFTSC})_{2}\left(\mathrm{CHCl}_{2^{-}}\right.\right.} \\
\left.\mathrm{COO})_{2}\right]\end{array}$} & $1^{\text {st }}$ & 211 & 282 & 501 & 30.8 \\
\hline & $2^{\text {nd }}$ & 502 & 597 & 736 & 43.3 \\
\hline
\end{tabular}

$\mathrm{T}_{\mathrm{i}}=$ Initial temperature $\quad \mathrm{T}_{\mathrm{m}}=$ Maximum temperature $\quad \mathrm{T}_{\mathrm{f}}=$ Final temperature

For compound $\left[\mathrm{Hg}(5 \mathrm{M} 3 \mathrm{HFTSC})_{2} \mathrm{Cl}_{2}\right]$ (Fig. 3) the TG curve is characterized by three decomposition steps at 191-278, 279-346 and $347-579^{\circ} \mathrm{C}$. The elimination of two $\mathrm{HCl}$ molecules (Calcd. 11.5\%, Found 11.7\%) is observed at the first step. This may suggest the existence of the species $\left[\mathrm{Hg}(5 \mathrm{M} 3 \mathrm{FTSC})_{2}\right]$ (eq. 4). It is assumed that the coordinated neutral ligand losses a proton and becomes to mononegative bidentate ligand. This step is composed of two DTG peaks at 220 and $242^{\circ} \mathrm{C}$ and two exotherms at 221 and $240^{\circ} \mathrm{C}$ in the DTA curve.

\section{$\left[\mathrm{Hg}(5 \mathrm{M} 3 \mathrm{HFTSC})_{2} \mathrm{Cl}_{2}\right]$

$$
\left[\mathrm{Hg}(5 \mathrm{M} 3 \mathrm{FTSC})_{2}\right]+2 \mathrm{HCl}
$$

The second step shows a loss of mass indicating an expulsion of $2 \mathrm{NH}_{2}$ radicals (eq. 5) which dimerize to $\mathrm{NH}_{2}-\mathrm{NH}_{2}$ (hydrazine eq. 6) (Cald. 5.0\%, Found 5.3\%) (DTG peak at $302^{\circ} \mathrm{C}$ ), for which an exothermic peak at $316^{\circ} \mathrm{C}$ is recorded in the DTA trace. The formation of this radical $\left(\mathrm{NH}_{2}\right)$ strongly points to a free mechanism starting by the preferential homolysis of N-C bond rather than N-N and C$\mathrm{C}$ bonds, according to their bond dissociation energy values of $42.2,66.4$ and $88.6 \mathrm{kcal} \mathrm{mol}^{-1}$, respectively ${ }^{37}$. The third step displays a major mass loss (49.3\%), which is characterized by two DTG peaks at 469 and $513^{\circ} \mathrm{C}$ and two exothermic effects at 465 and $517^{\circ} \mathrm{C}$ in the DTA trace. The destruction of the complex seems to follow a complicated course and lead to pure mercury oxide (Calcd. $34.0 \%$, Found $32.8 \%$ ) (eq. 6). The lower weight is probably due to partial sublimation of $\mathrm{HgO}$.

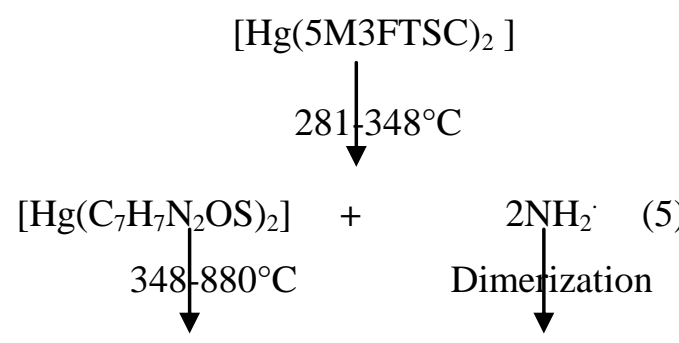

$\mathrm{HgO}+$ decomposition products $+\mathrm{NH}_{2}-\mathrm{NH}_{2}$

The thermolysis curve of $[\mathrm{Hg}(5 \mathrm{M} 3 \mathrm{HF}-$ $\left.\mathrm{TSC})_{2}\left(\mathrm{CF}_{3} \mathrm{COO}\right)_{2}\right]$ shows three inflection points indicating that the compound decomposes in three distinct steps in the temperature range 263-471, 473-628 and 628$742^{\circ} \mathrm{C}$ (Fig. 4). The observed mass loss of the first step is compatible with the loss of two $\left(\mathrm{CF}_{3} \mathrm{COOH}\right)$ molecules (Calcd. 28.5\%, Found $29.2 \%)$. The DrTG peak of this step occurs at $287^{\circ} \mathrm{C}$. An endothermic peak at $284^{\circ} \mathrm{C}$ is recorded in the DTA curve. The observed mass loss in the second step is supposed to be related to the detachment of 5-methyl-3-(furan) radicals which dimerize to $5,5^{\backslash}$ dimethyl-3,3 bifuran (calc.20.4\%, found 21.2\%). This step corresponds to a small peaks at 516 and $588^{\circ} \mathrm{C}$ in the DTG trace and an exothermic effect at $622^{\circ} \mathrm{C}$ (DTA). The third step represents a mass loss of $23.3 \%$. This step is manifested on the DrTG curve at $713^{\circ} \mathrm{C}$ and the DTA trace furnishes a small exothermic effect at $716^{\circ} \mathrm{C}$. The product remaining with $26.3 \%$ weight is calculated for $\mathrm{HgO}(27.3 \%)$.

The stepwise course of the thermogravimetric curve (Fig. 5) of the compound $\left[\mathrm{Hg}(5 \mathrm{M} 3 \mathrm{HFTSC})_{2}\left(\mathrm{CHCl}_{2} \mathrm{COO}\right)_{2}\right]$ is characterized by two decomposition steps in the 
temperature range $211-501$ and $502-736^{\circ} \mathrm{C}$.

The first mass loss accounts for the elimination of two $\mathrm{CHCl}_{2} \mathrm{COOH}$ molecules, (eq. 7), (Calcd. $31.1 \%$, Found $30.8 \%$ ) with a DrTG peak at $282^{\circ} \mathrm{C}$, and an endothermic peaks at $277^{\circ} \mathrm{C}$ in the DTA trace. The second step represents the decomposition of the ligand, (eq. 8), (Calcd. $44.5 \%$, Found $43.3 \%$ ). This step appears to be composed of two broad DrTG peaks at 599 and $703^{\circ} \mathrm{C}$, corresponding to three exothermic effects at 594, 649 and $703^{\circ} \mathrm{C}$ in the DTA trace. The mass loss consideration indicates that the left stable residue is $\mathrm{HgO}$ (Calcd. $26.3 \%$, Found $25.9 \%$ ).

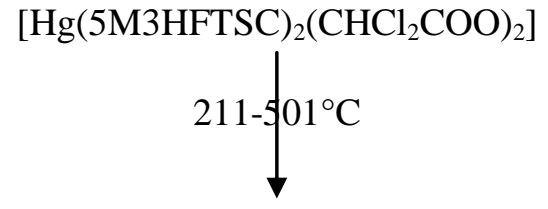

$\left[\mathrm{Hg}(5 \mathrm{M} 3 \mathrm{FTSC})_{2}\right]+2 \mathrm{CHCl}_{2} \mathrm{COOH}$

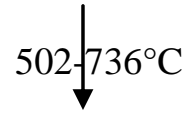

$\mathrm{HgO}+$ decomposition products

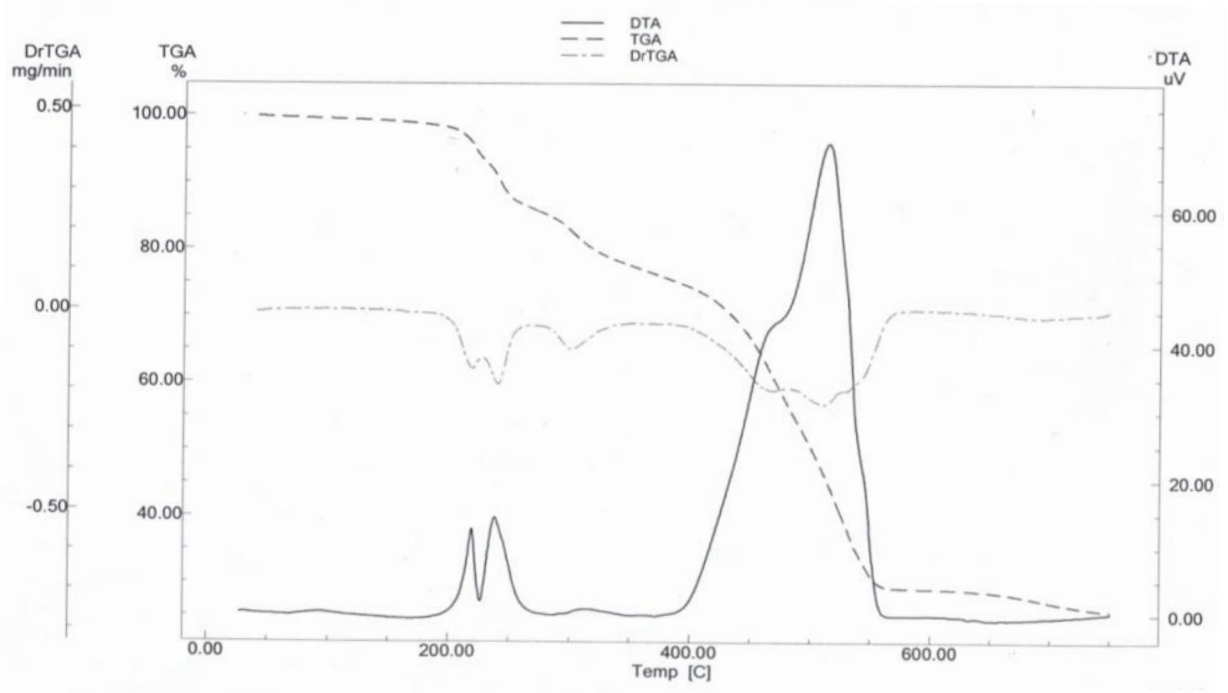

Fig. 3: $\operatorname{TGA}(---), \operatorname{DrTG}(\ldots$.$) and \mathrm{DTA}(\ldots)$ thermograms of $\left[\mathrm{Hg}(5 \mathrm{M} 3 \mathrm{HFTSC})_{2} \mathrm{Cl}_{2}\right]$.

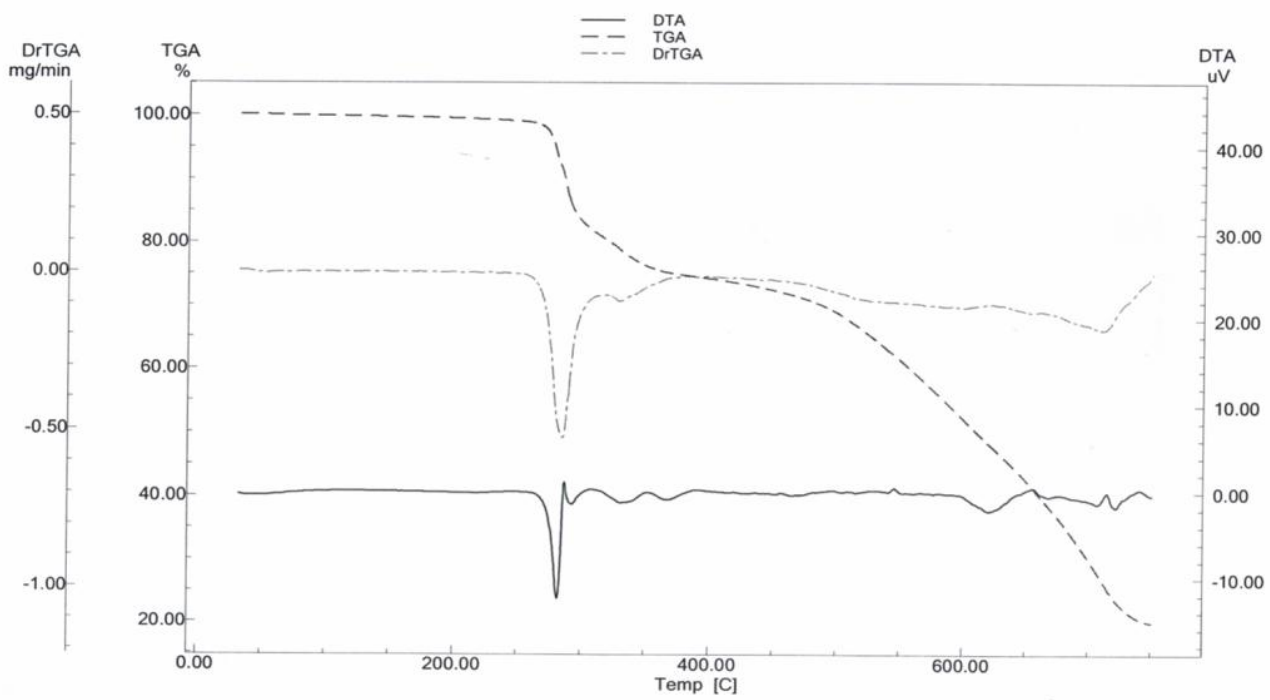

Fig. 4: TGA(---), DrTG(...) and DTA( _ _ $)$ thermograms of $\left[\mathrm{Hg}(5 \mathrm{M} 3 \mathrm{HFTSC})_{2}\left(\mathrm{CF}_{3} \mathrm{COO}\right)_{2}\right]$. 


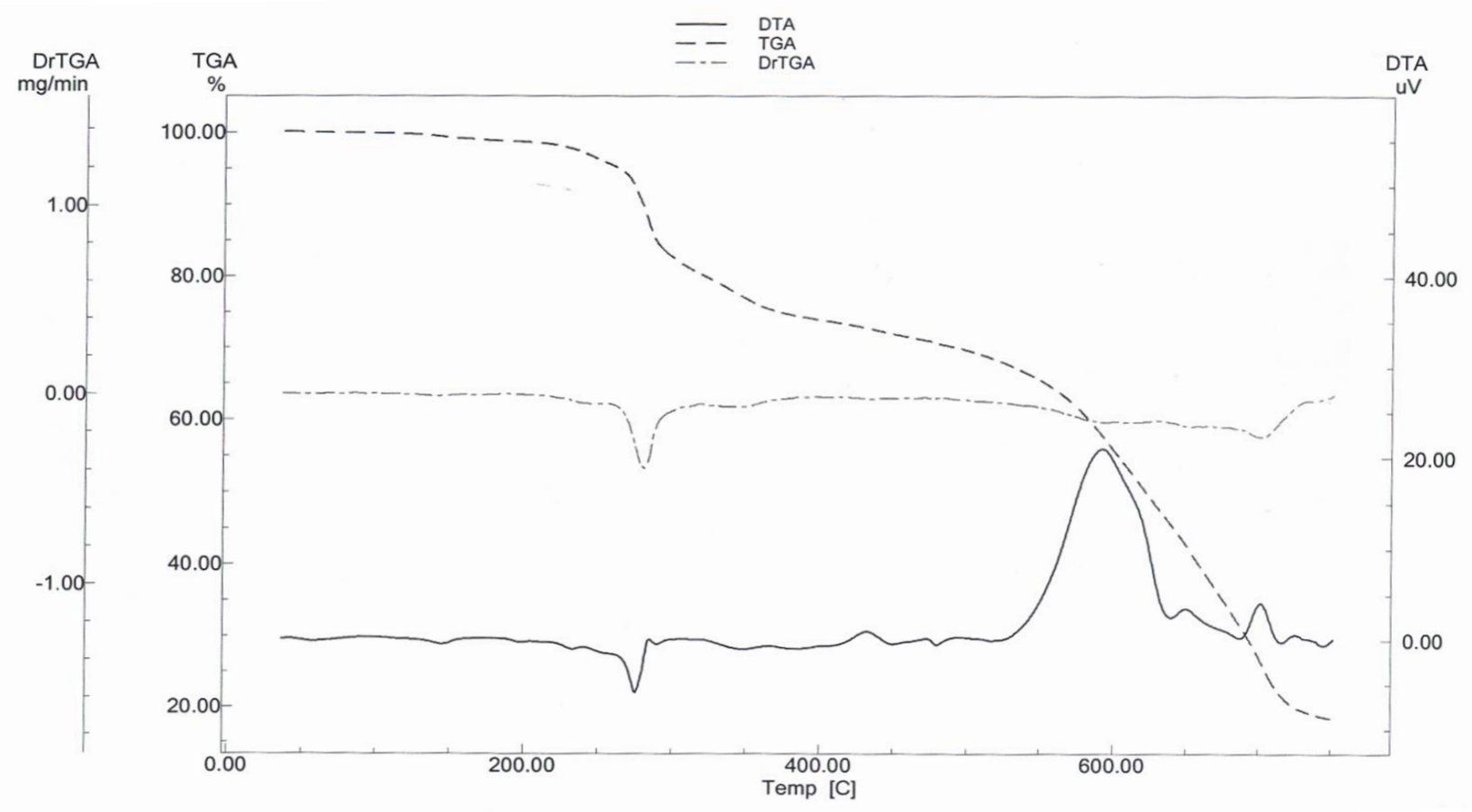

Fig. 5: $\operatorname{TGA}(---), \operatorname{DrTG}(\ldots)$ and $\mathrm{DTA}($ ) thermograms of $\left[\mathrm{Hg}(5 \mathrm{M} 3 \mathrm{HFTSC})_{2}\left(\mathrm{CHCl}_{2} \mathrm{COO}\right)_{2}\right.$.

\section{2- Kinetic analysis}

Nonisothermal kinetic analyses for the thermal decomposition of the complexes were carried out by the application of two different, Coats-Redfern $^{38}$ and Howowitz-Metzger ${ }^{39}$, equations. The kinetic parameters were evaluated only for clear-cut and nonoverlapping stages. The thermal data and kinetic parameters of the thermal decomposition of the complexes are included in table 5. The activation energies, in general, are relatively low indicating the low thermal stability of the complexes.

\section{Photochemical behaviour \\ 1- Photolyses of 5M3HFTSC}

Before the investigation of the photochemical behaviour of the prepared complexes, the photolyses of the free 5-methyl-3furaldehyde thiosemicarbazone was studied.

The spectral changes recorded during photolysis of 5M3HFTSC in DMF solution upon irradiation with cut-on filter of $\lambda_{\text {irr }} \geq 299$ $\mathrm{nm}$ showed decreased in absorbance at $333 \mathrm{~nm}$ (Fig. 6).

\section{2-Photolysis of the $\mathrm{Hg}$ (II) complexes}

Upon irradiation with light of $\lambda_{\text {irr }} \geq 299$ $\mathrm{nm}$, the DMF solution of $\left[\mathrm{Hg}(5 \mathrm{M} 3 \mathrm{HFTSC})_{2^{-}}\right.$
$\left.\mathrm{Cl}_{2}\right], \quad\left[\mathrm{Hg}(5 \mathrm{M} 3 \mathrm{HFTSC})_{2}\left(\mathrm{CF}_{3} \mathrm{COO}\right)_{2}\right] \quad$ and $\left[\mathrm{Hg}(5 \mathrm{M} 3 \mathrm{HFTSC})_{2}\left(\mathrm{CHCl}_{2} \mathrm{COO}\right)_{2}\right]$ complexes under investigation exhibited a light sensitivity, and the absorbance at $333 \mathrm{~nm}$ decreased. The behaviour of $\left[\mathrm{Hg}(5 \mathrm{M} 3 \mathrm{HFTSC})_{2}\left(\mathrm{CF}_{3} \mathrm{COO}\right)_{2}\right]$, is depicted in figure 7 as an example.

\section{3-Photolysis in the presence of $\mathrm{H}_{2} \mathrm{O}_{2}$}

The spectral changes of 5M3HFTS and their complexes in DMF solutions in the presence of $\mathrm{H}_{2} \mathrm{O}_{2}$ upon irradiation with light $\lambda_{\text {irr }}$ $\geq 299 \mathrm{~nm}$ at room temperature $\left(25^{\circ} \mathrm{C}\right)$ are very fast compared with that in absence of $\mathrm{H}_{2} \mathrm{O}_{2}$ at the same conditions (Figs $8 \& 9$ ).

The $\mathrm{UV} / \mathrm{H}_{2} \mathrm{O}_{2}$ oxidation process is of potential practical important ${ }^{40}$. It is characterized by the generation of a very powerful oxidizing species, namely hydroxyl radicals ${ }^{41}$. The general pattern of the reactions of these radicals with saturated aliphatic products involves abstraction of an $\mathrm{H}$ atom (or $\mathrm{H}^{+}$ion) in the rate-determing step $^{42}$. On the other hand, when the organic molecule contains a double bond, the abstraction of $\mathrm{H}$ atom is competed by an addition of $\mathrm{OH}$ radicals on this unsaturated bond ${ }^{43}$. 


\section{Biological activity}

The 5-methyl-3-furaldehyde $\mathrm{Hg}$ (II) complexes under investigation were tested against some bacteria and fungi (Table 6). The bacteria and fungi namely: Bacillus cereus (Gram positive), Staphylococcus aureus (Gram positive), Escherichia coli (Gram negative), Pseudomonas aeruginosa (Gram negative), Aspergillus flavus, Aspergillus niger, Candida albicans, Fusarium oxysporum, Geotrichum candidum, Pencillinum purpurogenum, Chloramphenicol and Dermatin as antibacterial and antifungal were used as standards, respectively.

A critical examination of the antimicrobial action of these compound indicates that in general the mixed ligand complexes are better toxic agents against various bacteria and fungi than the $\left[\mathrm{Hg}(5 \mathrm{M} 3 \mathrm{HFTSC})_{2} \mathrm{Cl}_{2}\right]$ complex and the 5M3HFTSC ligand.

The antimicrobial activity of metal ion complexes were explain several workers ${ }^{44 \& 45}$ assuming that the neutral complexes mixes ligand complexes first penetrate the cell and at the site of action undergo dissociation to 1: 1 complexes which will become toxic by blocking the metal binding sites on enzymes. This can proposed for the complexes included in table 6.

Table 5 : Kinetic parameters for the thermal decomposition of $\mathrm{Hg}(\mathrm{II})$ complexes using nonmechanistic equations.

\begin{tabular}{|c|c|c|c|c|c|c|c|c|c|}
\hline \multirow{2}{*}{ Compound } & \multirow{2}{*}{ Step } & \multicolumn{4}{|c|}{ Coats-Redfern equation } & \multicolumn{4}{|c|}{ Horowitz-Metzger equation } \\
\hline & & $\mathrm{n}$ & $r$ & $\mathrm{E}$ & $\bar{Z}$ & $\mathrm{n}$ & $r$ & $\mathrm{E}$ & $\bar{Z}$ \\
\hline \multirow{6}{*}{$\begin{array}{c}{\left[\mathrm{Hg}(5 \mathrm{M} 3 \mathrm{HFTSC})_{2}\right)} \\
\left.\mathrm{Cl}_{2}\right]\end{array}$} & \multirow{6}{*}{$1^{\mathrm{st}}$} & 0.00 & 0.9992 & 193.2 & $4.20 \times 10^{5}$ & 0.00 & 0.9987 & 188.2 & $1.28 \times 10^{5}$ \\
\hline & & 0.33 & 0.9992 & 101.3 & $3.31 \times 10^{6}$ & 0.33 & 0.9991 & 197.6 & $1.51 \times 10^{6}$ \\
\hline & & 0.50 & 0.9992 & 217.4 & $1.34 \times 10^{7}$ & 0.50 & 0.9993 & 221.4 & $2.30 \times 10^{8}$ \\
\hline & & 0.66 & $\underline{0.9999}$ & 232.8 & $2.73 \times 10^{7}$ & 0.66 & $\underline{1}$ & 238.4 & $2.54 \times 10^{8}$ \\
\hline & & 1.00 & 0.9992 & 246.8 & $5.13 \times 10^{9}$ & 1.00 & 0.9989 & 252.3 & $2.25 \times 10^{10}$ \\
\hline & & 2.00 & 0.9984 & 312.4 & $3.21 \times 10^{15}$ & 2.00 & 0.9979 & 321.1 & $1.11 \times 10^{16}$ \\
\hline \multirow{6}{*}{$\begin{array}{c}{\left[\mathrm{Hg}(5 \mathrm{M} 3 \mathrm{HFTSC})_{2}\right.} \\
\left.\left(\mathrm{CF}_{3} \mathrm{COO}\right)_{2}\right]\end{array}$} & \multirow{6}{*}{$1^{\mathrm{st}}$} & 0.00 & 0.9979 & 69.8 & $1.62 \times 10^{6}$ & 0.00 & 0.9986 & 78.8 & $1.41 \times 10^{7}$ \\
\hline & & 0.33 & 0.9999 & 86.4 & $1.12 \times 10^{7}$ & 0.33 & 0.9993 & 85.4 & $4.24 \times 10^{8}$ \\
\hline & & 0.50 & 0.9998 & 95.5 & $1.08 \times 10^{8}$ & 0.50 & 0.9989 & 98.5 & $2.41 \times 10^{9}$ \\
\hline & & 0.66 & $\underline{1}$ & 108.9 & $3.29 \times 10^{9}$ & 0.66 & $\underline{1}$ & 111.9 & $2.21 \times 10^{10}$ \\
\hline & & 1.00 & 0.9997 & 122.1 & $4.51 \times 10^{11}$ & 1.00 & 0.9999 & 128.4 & $1.22 \times 10^{12}$ \\
\hline & & 2.00 & 0.9971 & 251.5 & $2.52 \times 10^{19}$ & 2.00 & 0.9979 & 252.5 & $1.23 \times 10^{19}$ \\
\hline \multirow{6}{*}{$\begin{array}{c}{\left[\mathrm{Hg}(5 \mathrm{M} 3 \mathrm{HFTSC})_{2}\right.} \\
\left.\left(\mathrm{CHCl}_{2} \mathrm{COO}\right)_{2}\right]\end{array}$} & \multirow{6}{*}{$1^{\mathrm{st}}$} & 0.00 & 0.9994 & 112.1 & $1.05 \times 10^{7}$ & 0.00 & 0.9997 & 121.2 & $2.14 \times 10^{7}$ \\
\hline & & 0.33 & 0.9978 & 142.3 & $1.24 \times 10^{8}$ & 0.33 & 0.9989 & 152.1 & $1.60 \times 10^{7}$ \\
\hline & & 0.50 & 0.9983 & 159.5 & $1.13 \times 10^{9}$ & 0.50 & 0.9984 & 169.4 & $1.05 \times 10^{9}$ \\
\hline & & 0.66 & $\underline{1}$ & 181.0 & $1.03 \times 10^{11}$ & 0.66 & 1 & 188.5 & $3.14 \times 10^{10}$ \\
\hline & & 1.00 & $\underline{1}$ & 208.4 & $1.13 \times 10^{13}$ & 1.00 & 0.9999 & 202.3 & $3.16 \times 10^{11}$ \\
\hline & & 2.00 & 0.9993 & 292.7 & $1.12 \times 10^{17}$ & 2.00 & 0.9991 & 296.1 & $2.14 \times 10^{16}$ \\
\hline
\end{tabular}

$\mathrm{E}$ in $\mathrm{kJ} \mathrm{mol}^{-1} ; \mathrm{Z}_{\text {in s}}{ }^{-1}$ underlined $r$ in all tables represent the best fit values of $\mathrm{n}, \mathrm{E}$ and $\mathrm{Z}$ $\mathrm{n}=$ order of the decomposition reaction $\mathrm{r}=$ correlation coefficient $\mathrm{E}=$ activation energy of decomposition $\mathrm{Z}=$ preexponential factor 


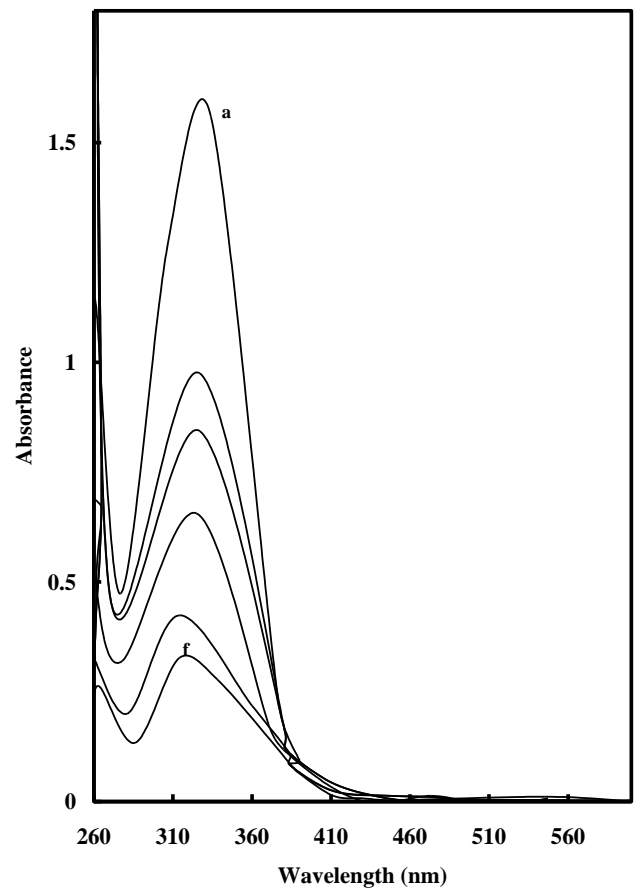

Fig. 6: Spectral changes during the photolysis of 5methyl-3-feuraldehyde-thiosemicarbazone (5M3HFTSC) in DMF; at irradiation time of $\mathrm{a}=0, \mathrm{~b}=3, \mathrm{c}=5, \mathrm{~d}=7, \mathrm{e}=8$ and $\mathrm{f}=9 \mathrm{~min}$, $\lambda_{\text {irr }} \geq 299 \mathrm{~nm}, 1-\mathrm{cm}$ cell.

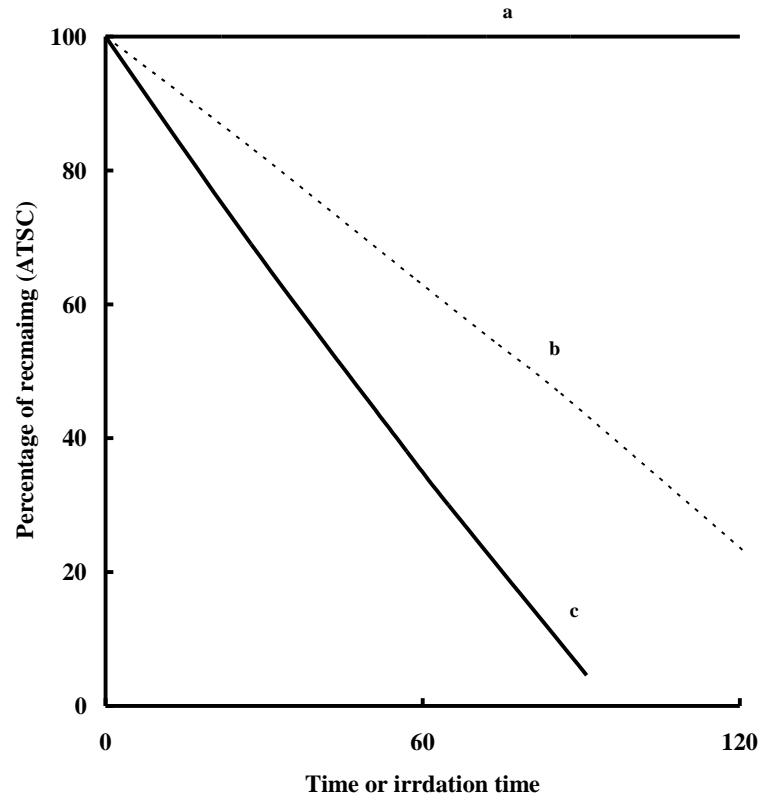

Fig. 8: Percentage of 5M3HFTSC remaining as a function of time or irradiation time; (a) in dark and in presence of $\mathrm{H}_{2} \mathrm{O}_{2}$, (b) under illumination with light of $\lambda_{\text {irr }} \geq 299 \mathrm{~nm} \mathrm{a}$ without $\mathrm{H}_{2} \mathrm{O}_{2}$, (c) under illumination with light of $\lambda_{\text {irr }} \geq 299 \mathrm{~nm}$ and in presence of $\mathrm{H}_{2} \mathrm{O}_{2}$.

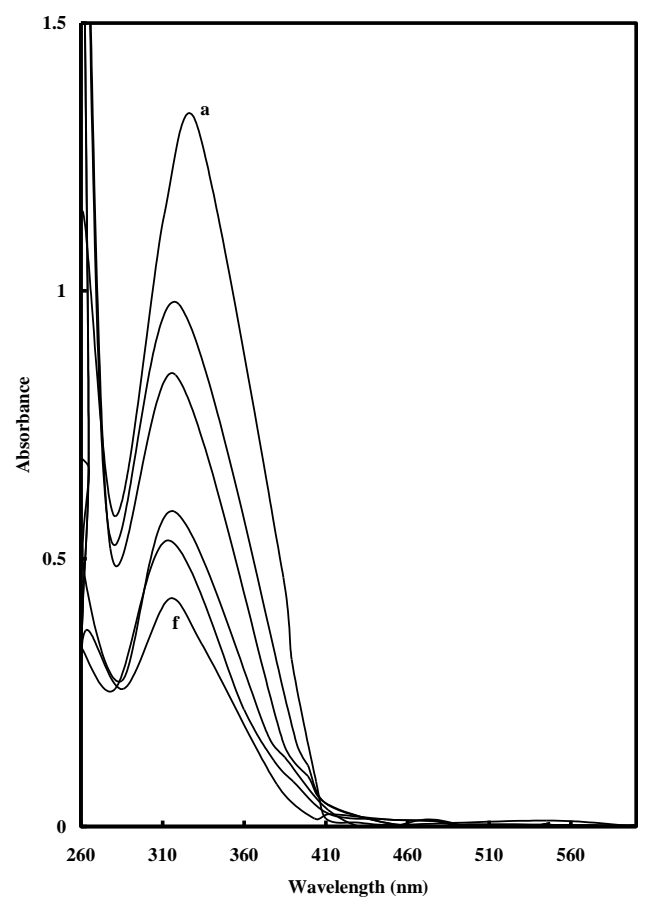

Fig. 7: Spectral changes during the photolysis of $\left[\mathrm{Hg}(5 \mathrm{M} 3 \mathrm{HFTSC})_{2}\left(\mathrm{CF}_{3} \mathrm{COO}\right)_{2}\right]$ in DMF; at irradiation time of $a=0, b=3, c=6, d=12$, e= 16 and $\mathrm{f}=20 \mathrm{~min}, \lambda_{\text {irr }} \geq 299 \mathrm{~nm}, 1-\mathrm{cm}$ cell.

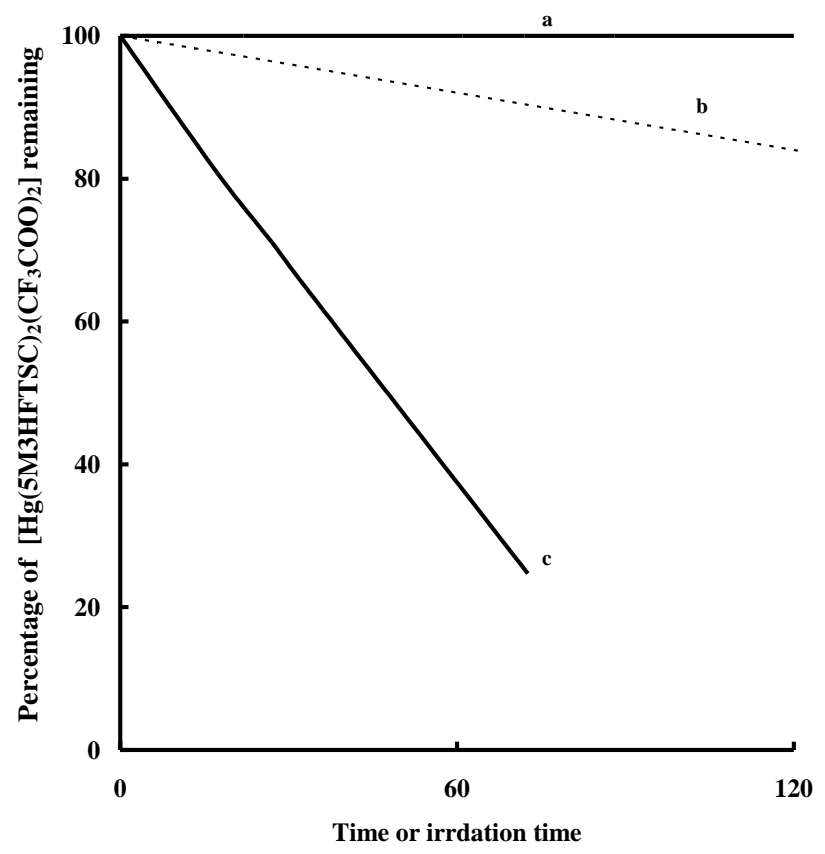

Fig. 9: Percentage of $\left[\mathrm{Hg}(5 \mathrm{M} 3 \mathrm{HFTSC})_{2}\left(\mathrm{CF}_{3}-\right.\right.$ $\mathrm{COO})_{2}$ ] remaining as a function of time or irradiation time; (a) in dark and in presence of $\mathrm{H}_{2} \mathrm{O}_{2}$, (b) under illumination with light of $\lambda_{\text {irr }} \geq 299 \mathrm{~nm}$ a without $\mathrm{H}_{2} \mathrm{O}_{2}$, (c) under illumination with light of $\lambda_{\text {irr }} \geq 299 \mathrm{~nm}$ and in presence of $\mathrm{H}_{2} \mathrm{O}_{2}$. 
Table 6: Microbiological screening of 5M3HFTSC and their complexes.

\begin{tabular}{|c|c|c|c|c|c|c|c|c|c|c|}
\hline Complex & $\begin{array}{c}\text { B. } \\
\text { cereus } \\
(\mathrm{G}+\mathrm{ve}) \\
\end{array}$ & $\begin{array}{c}S . \\
\text { aureus } \\
(\mathrm{G}+\mathrm{ve}) \\
\end{array}$ & $\begin{array}{c}E \\
\text { coli } \\
(\mathrm{G}-\mathrm{ve}) \\
\end{array}$ & $\begin{array}{c}P . \\
\text { aeruginosa } \\
\text { (G-ve) } \\
\end{array}$ & $\begin{array}{l}\text { A. } \\
\text { flavus }\end{array}$ & $\begin{array}{l}\text { A. } \\
\text { niger }\end{array}$ & $\begin{array}{c}C . \\
\text { albicans }\end{array}$ & $\begin{array}{c}F . \\
\text { oxysporm }\end{array}$ & $\begin{array}{c}G . \\
\text { candidum }\end{array}$ & $\begin{array}{c}P . \\
\text { purpurogenum }\end{array}$ \\
\hline 5M3HFTSC & 0 & 9 & 8 & 9 & 7 & 0 & 0 & 0 & 0 & 20 \\
\hline $\begin{array}{l}{\left[\mathrm{Hg}(5 \mathrm{M} 3 \mathrm{HFTSC})_{2}\right.} \\
\left.\mathrm{Cl}_{2}\right]\end{array}$ & 11 & 18 & 19 & 10 & 12 & 7 & 14 & 0 & 0 & 13 \\
\hline $\begin{array}{l}\mathrm{Hg}(5 \mathrm{M} 3 \mathrm{HFTSC})_{2} \\
\left.\left(\mathrm{CF}_{3}-\mathrm{COO}\right)_{2}\right]\end{array}$ & 36 & 33 & 29 & 11 & 22 & 33 & 24 & 17 & 26 & 25 \\
\hline $\begin{array}{l}\mathrm{Hg}(5 \mathrm{M} 3 \mathrm{HFTSC})_{2} \\
\left.\left(\mathrm{CHCl}_{2}-\mathrm{COO}\right)_{2}\right]\end{array}$ & 39 & 37 & 27 & 13 & 26 & 34 & 28 & 15 & 29 & 23 \\
\hline $\begin{array}{c}\text { Standard* } \\
\text { (Antibacterial) } \\
\text { (Antifungal) }\end{array}$ & 50 & 30 & 38 & 52 & 40 & 23 & 11 & 20 & 21 & 25 \\
\hline
\end{tabular}

*Standard, Antibacterial $=$ Chloramphenicol, antifungal $=$ Dermatin

\section{REFERENCES}

1- M. Wang, L. F. Wang, Y. Z. Li, Q. X. Li, Z. D. $\mathrm{Xu}$ and D. M. Qu, Trans. Met. Chem., 26, 307 (2001).

2- L. D. S. Yadav and S. Singh, Indian J. Chem., 40B, 440 (2001).

3- E. Labisbal, A. Sousa, A. Castineiras, A. Gracia-Vazquez, J. Romero and D. X. West, Polyderon, 19, 1255 (2000).

4- M. K. Srivastava, B. Mishra and M. Nizamuddin, Indian J. Chem., 40B, 342 (2001).

5- D. K. Dermertzi, N. Kourkoumelis, M. A. Dermertzis, J. R. Miller, C. S. Frampton, J. K. Swearingen and D. X. West, Eur. J. Inorg. Chem., 727 (2000).

6- M. A. Ali, A. H. Mirza, A. Monsur, S. Hussain and M. Nizamuddin, Polyhedron, 20, 1045 (2001).

7- A. A. M. Ali, M. S. EL-Meligy, A. S. Zidan and M. EL-Shabasy, An. Quim., 86, 19 (1990).

8- M. Joseph, V. Suni, M. R. P. Kurup, M. Nethaji, A. Kishore and S. G. Bhat, Polyhedron, 23, 3069 (2004).

9- E. Jouad, M. Allain, M. A. Khan and G. M. Bouet, ibid, 23, 1 (2004).

10- Z. Yin and R. Dong, Synth. React. Inorg. Met.-Org. Chem., 32, 1059 (2002).

11- C. H. Collins, P. M. Lyne, "Microbiological Methods", Univerisity Park Press, Baltimore, 1970, p 422.

12- W. J. Geary, Coord. Chem. Rev., 7, 81 (1971).
13- S. Chandra, Sangeetika and A. Rathi, J. Saudi. Chem. Soc., 5, 175 (2001).

14- H. Temel and H. Hosgoren, Trans. Met. Chem., 27, 609 (2002).

15- A. A. El-Asmy, O. A. El-Gammal and H. S. Saleh, Spectrochem. Acta., A, 71, 39 (2008).

16- S. Renjusha and M. R. P. Kurup, Polyhedron, 27, 3294 (2008).

17- X. Li, Y. Wu, D. Gu and F. Gan, Dyes and Pigments, 86, 182 (2010).

18- R. C. Chikate and S. B. Padhye, Spectrochim. Acta., 66A, 1091 (2007).

19- I. C. Mendes, M. A. Soares, R. G. Santos, C. Pinheiro and H. Beraldo, Eur. J. Med. Chem., 44, 1870 (2009).

20- J. G. Silva, L. S. Azzolini, S. M. S.V. Wardell, J. L. Wardell and H. Beraldo, Polyhedron, 28, 2301 (2009).

21- J. Chan, A. L. Thompson, M. W. Jones and J. M. Peach, Inorg. Chim. Acta., 363, 1140 (2010).

22- C. R. Kowol, R. Eichinger, M. A. Jakupec, M. Galanski, V. B. Arion and B. K. Keppler, J. Inorg. Biochem., 101, 1946 (2007).

23- T. S. Lobana, R. Sharma, G. Bawa and S. Khann, Coord. Chem. Rev., 53, 977 (2009).

24- G. Bandoli, A. Dolmella, F. Tisato, M. Porchia and F. Refosco, ibid., 253, 56 (2009).

25- B. Rezaei, E. Sadeghi and S. Meghdadi, J. Hazardous Mat., 168, 787 (2009). 
26- D. X. West, M. A. Lockwood, A. E. Liberta, X. Chen and R.D. Willett, Trans. Met. Chem., 18, 221 (1993).

27- P. K. Singh, J. K. Koacher and J. P. Tondon, J. Inorg. Nucl. Chem., 43, 1755 (1981).

28- K. Nakamoto, "Infrared and Raman Spectra of Coordination Compounds", Wiley Interscience, New York (1970).

29- A. Vogler, and H. Kunkely, Coord. Chem. Rev., 251, 577 (2007).

30- A. A. El-Asmy, Y. M. Shaiba, I. M. Shedaiwa and M. A. Kattab, Synth. React. Inorg. Met. Org. Chem., 18, 331 (1988).

31- C. M. Duan, Y. P. Tian, C. Y. Zhao, X. Z. You and T. C. W. Mak, Polyhedron, 16, 2857 (1997).

32- J. S. Casas and M. S. Garcia-Tasende. J. Coord. Chem. Rev., 209, 197 (2000).

33- A. Castineiras, I. Garcia, E. Bermego and D. X. West, Polyhedron, 19, 1873 (2000).

34- R. M. El- Shazly, G. A. A. Al-Hazmi, S. E. Ghazy, M. S. El-Shahawi and A. A. ElAsmy, Spectrochem. Acta, 61A, 243 (2005).

35- G. A. A. Al-Hazmi, M. S. El-Shahawi, I. M. Gaber and A. A. El-Asmy, J. Coord. Chem., 58, (8), 713 (2005).
36- G. A. A. Al-Hazmi, M. S. El-Shahawi and A. A. El-Asmy, Tran. Met. Chem., 30, 464 (2005).

37- R. C. Weast, "Handbook of Chemistry and Physics", CRC Press, Boca Raton, FL, 1982, p. 195.

38- A. W. Coats and J. P. Redfern, Nature, 20, 68 (1964).

39- H. H. Horowitze and G. Metzger, Anal. Chem., 35, 1464 (1963).

40- M. Muruganadham and M. Swaminathain, Dyes and Pigments, 62, 269 (2004).

41- A. M. L. Marechal, Y. M. Solkar and T. Taufer, ibid., 33, 281 (1997).

42- A. H. Osman, A. A. M. Aly, M. Abd ElMottaleb and G. A. H. Gouda, Bull. Korean. Chem. Soc., 25, 45 (2004).

43- G. M. Colonna, T. Caronna and B. Marcandalli, Dyes and Pigments, 41, 211 (1999).

44- G. A. Zetmyer, S. Rich and J. C. Horsfall, Phyto., 50, 21 (1960).

45- H. Gershon, R. Parmegiani, A. Weiner and R. Ascoli, Contri. Boyce Thomeson Inst., 23, 219 (1966). 